WMJ (Warmadewa Medical Journal), Vol. 6 No. 2 November 2021, Hal. 46-56

\title{
Capsaicin 8\% Patch for Alternative Therapy of Painful Diabetic Peripheral Neuropathy
}

\author{
Muhammad Luthfi Adnan \\ Faculty of Medicine, Universitas Islam Indonesia, Sleman, Indonesia \\ Email:luthfiadnan35@yahoo.co.id
}

\begin{abstract}
Diabetes is one of the most common health problems due to its high incidence and complications. One of the complications associated with diabetes is painful diabetic peripheral neuropathy (PDPN). The capsaicin $8 \%$ patch is a localized pain treatment that provides effective pain relief from a single application in patients with peripheral neuropathic pain. The aim of this review is to discuss the effect of capsaicin patch $8 \%$ in patients with painful diabetic peripheral neuropathy. The search strategy was conducted in PubMed and modified for other databases. The search was limited to English-language reports. The keywords used were "capsaicin", "capsaicin patch", "painful diabetic peripheral neuropathy", and "pain management". The inclusion criteria used were randomized controlled trials (RCTs), clinical trials or another interventional analysis with full text in English with publications less than the last 10 years. The exclusion criteria used were a review, systematic review, or meta-analysis, studies that were not conducted in humans and non-full text in English with publications over the last 10 years. Results: There are 2 full-text that meet inclusion criteria. From articles related to studies that have been conducted, the use of capsaicin $8 \%$ patch can reduce pain, improve nerve function and quality of life in PDPN patients. The use of capsaicin $8 \%$ patch has the advantage to pain relief for patients with painful diabetic peripheral neuropathy.
\end{abstract}

Keywords: Alternative therapy, Capsaicin 8\% Patch, Diabetes complications, Pain Relief, Painful Diabetic Peripheral Neuropathy, topical drugs

\section{Abstrak \\ [Capsaicin 8\% Patch untuk Terapi Alternatif Neuropati Perifer Diabetik yang Menyakitkan]}

Diabetes merupakan salah satu permasalahan kesehatan karena insidensi yang tinggi dan komplikasinya. Salah satu komplikasi terkait diabetes adalah nyeri neuropati diabetikum perifer/painful diabetic peripheral neuropathy (PDPN). Capsaicin 8\% patch merupakan pengobatan nyeri yang terlokalisir yang menyediakan pereda nyeri pada pasien dengan nyeri neuropati perifer. Tujuan dari tinjauan ini adalah untuk membahas efek capsaicin patch $8 \%$ pada pasien dengan nyeri neuropati perifer diabetikum. Pencarian literatur dilakukan dengan menggunakan mesin pencari PubMed dan sumber data terkait lainnya. Pencarian terbatas pada studi berbahasa Inggris. Kata kunci yang digunakan antara lain "capsaicin", "capsaicin patch", "painful diabetic peripheral neuropathy", dan "pain management". Kriteria inklusi yang digunakan antara lain studi berupa randomized controlled trials (RCTs), clinical trials atau studi intervensi lainnya dengan full text berbahasa Inggris dengan publikasi kurang dari 10 tahun. Kriteria eksklusi yang digunakan adalah studi berupa tinjauan, tinjauan sistematis, atau meta-analisis, studi tidak dilakukan pada manusia, bukan full text berbahasa Inggris dengan riwayat publikasi lebih dari 10 tahun. Terdapat dua studi yang memenuhi kriteria inklusi. Dari artikel studi yang telah dilakukan, penggunaan capsaicin $8 \%$ patch dapat menurunkan nyeri, memperbaiki fungsi saraf dan kualitas hidup pasien dengan nyeri neuropati perifer diabetikum. Penggunaan capsaicin $8 \%$ patch memiliki keuntungan pereda nyeri untuk pasien nyeri neuropati perifer diabetikum.

Kata kunci: capsaicin $8 \%$ patch, komplikasi diabetes, nyeri neuropati perifer diabetikum, obat topikal, pereda nyeri, terapi alternatif

\section{INTRODUCTION}

Diabetes is one of the most common health problems due to its high incidence and complications. ${ }^{1}$ The prevalence of diabetes patients has reached 476 million worldwide, with 462 million of them being T2DM patients or the equivalent of $6.28 \%$ of the world's population. ${ }^{2,3}$ By 2025 , diabetes is projected to increase to 570.9 million with an increase in the death rate from 
diabetes reaching 1.59 million each year. ${ }^{3}$ The prevalence of diabetes-related complications reached $18.8 \%$ microvascular complications and $12.7 \%$ macrovascular complications. $^{4}$

One of the common complications associated with diabetes is painful diabetic peripheral neuropathy (PDPN). ${ }^{5}$ PDPN is defined as "the presence of symptoms and/ or signs of peripheral nerve dysfunction in people with diabetes after the exclusion of other causes" which is characterized by burning or stabbing pain, tingling, hyperesthesia, or an electric shock-like sensation. PDPN can result in decreased quality of life for diabetic patients and increase diabetesrelated care costs. ${ }^{6}$ PDPN symptoms can appear after 10 years of diagnosis and $20 \%$ of diabetic patients are diagnosed with PDPN at the same time as the diagnosis of diabetes. ${ }^{7}$ Although several studies have shown the effect of glucose control on neurological pain-related complications in diabetic patients, its effectiveness is unclear because some studies have shown the opposite result. ${ }^{8}$

Topical treatment is an alternative management of PDPN. ${ }^{9}$ One of the topical drugs that can be used as a topical treatment for PDPN is capsaicin, a natural alkaloid that often found in chillies. ${ }^{9,10}$ Currently, there are two capsaicin dosage measures for topical drugs, namely low dose $(0.075 \%)$ and high dose $(8 \%){ }^{9}$ The capsaicin $179 \mathrm{mg}$ ( $8 \%$ weight for weight) cutaneous patch (capsaicin $8 \%$ patch) is a localized pain treatment that provides effective pain relief from a single application in patients with peripheral neuropathic pain with faster analgesics and fewer side effects versus oral analgesic therapy. ${ }^{11}$

Capsaicin $8 \%$ patch has been widely used to help relieve pain syndrome although results were inconsistent. ${ }^{12}$ Several studies have shown that the effect of the capsaicin $8 \%$ patch can reduce pain intensity with the same effectiveness as orally systemic pain relief (eg pregabalin, gabapentin) with fewer systemic side effects (drowsiness, vomiting, fatigue). ${ }^{13}$ However, there are still few studies related to the use of capsaicin $8 \%$ patch so that its effectiveness is still limited to a small population. The aim of this review was to understand the effect of using the capsaicin $8 \%$ patch for pain relief in PDPN patients.

\section{METHOD \\ Search strategy}

The systemic literature review was conducted based on the Preferred Reporting Items for Systematic Reviews and Meta -Analysis (PRISMA) guideline. The search strategy was with search engine PubMed and modified for other databases (Google Scholar, Science Direct) from AugustusOctober 2020. The search was limited to English-language reports and published less than 10 years. The keywords used were "capsaicin", "capsaicin patch", "painful diabetic peripheral neuropathy", and "pain management".

\section{Study selection}

The following title and abstract keyword search terms were used in all databases, with limitations to humans. The inclusion criteria used were randomized controlled trials (RCTs), clinical trials or other interventional study with full text in English with publications less than the last 10 years. The study was considered eligible when using patients who had been diagnosed with PDPN. There were no restrictions placed on duration, intensity, or setting of intervention (i.e., inpatient and outpatient). The exclusion criteria used were a review, systematic review, or metaanalysis with non-full text in English. The studies that were conducted not in human and not in patient who had been diagnosed with PDPN also excluded. The study selection process began with general keyword (from title and abstract) searching in the databases and reference lists of appropriate studies. From those titles and abstracts that appeared relevant, a more thorough abstract review was conducted and all eligible full-text articles were included in this paper. 


\section{Data extraction and assessment of stud- ies}

The author extracted and collated all details of the data items and study characteristics from all articles. Data extraction table including, if available, sample size, country, mean of age, duration of PDPN, history of pain medication before study, type and duration of study, type of intervention, primary and secondary outcome, and any adverse event that reported. All data from extraction then were input into table.

\section{RESULT \\ Study selection}

Based on the flowchart that describes the identification, screening, exclusion, eligibility, and selection processes as shown in Figure 1, 315 studies were identified in the search system with 256 of them excluded because based on the title and abstract review, it was identified that the studies carried out were not in English, the study was systematic reviews or reviews or metaanalysis, case studies and not full text. Of the 59 articles that passed the screening process, a full review was carried out and excluded 57 articles with most of the studies conducted not on PDPN patients and carried out in test animals or in vitro studies.

\section{Study characteristic}

Characteristics of patients and description of interventions are shown in Table 1 and 2. The studies were limited to the United States and Europe (country specification not specified) with sample sizes ranging from 155 to 186 people in adults (ranging in age from 59.1 to 63.9 years). The study sample had diagnosed PDPN ranging from 4.1 to 5.8 years with most of the use of analgesic drugs to treat PDPN. The study reported the racial composition of the sample which was predominantly Caucasian (71.0-99.4\%). The population sample had levels of $\mathrm{HbA} 1 \mathrm{C} \geq 6.5 \%$ and body mass index (BMI) $\geq 30 \mathrm{~kg} / \mathrm{m} 2$. All studies performed using the Capsaicin 8\% patch (Qutenza; Acorda Therapeutics, Inc, Ardsley, NY; obtained from Astellas Pharma Europe BV, Leiden, The Netherlands). One study compared an intervention with a placebo patch for 30 minutes and another with a standard care and a difference in duration of 30 minutes and 60 minutes.

\section{Outcome measures}

All studies reported primary outcome and secondary outcome showed in Table 3. The outcomes were measured from baseline until the end of study. Outcome measures include daily pain score, treatment satisfaction, quality of life, sensory perception and reflex testing, adverse sign, and other pain medication during the study.

\section{Primary outcome}

Simpson et al showed that intervention group had significant reduction in average daily pain score of the Numeric Pain Rating Scale (NPRS) from 2-8 weeks (-27.4\% vs $-20.9 \%$; 95\% CI, -12.3 to -0.8 ; $\mathrm{P}=0.025)$ and $2-12$ weeks $(-28.0 \%$ vs $21.0 \% ; 95 \% \mathrm{CI},-12.9$ to $-1.2 ; \mathrm{P}=0.018)$ after intervention. ${ }^{14}$ Vinik et al showed there were reduction of mean change of Norfolk Quality of Life-Diabetic Neuropathy (QOL-DN) from baseline (estimated mean difference versus SOC alone; $90 \%$ CI for difference) of patients which treated with 30 minute use capsaicin $8 \%$ patch and standard of care (SOC) $27.6 \%(-20.9 \%$; 95\% CI, -31.7 to -10.1$)$, treated with 60 minute use capsaicin $8 \%$ patch and SOC $-32.8 \%(-26.1 ; 95 \% \mathrm{CI}$, 36.8 to -15.4 ), and SOC alone $-6.7 \%$. ${ }^{15}$ The reduction of QOL-DN score was associated with improved function of sensory nerve and quality of life.

\section{Secondary outcome}

Simpson et al showed that intervention group had significant modest improvements in sleep interference scores (from NPRS) from baseline to between weeks 2 through $8(\mathrm{P}=0.03)$ and weeks 2 through $12(\mathrm{P}=0.02)$. This study also showed patient satisfaction of therapy and life (from Patient Global Impression of Change and Self-Assessment of Treatment II question- 
naire) but not significant change in healthrelated quality of life (no significance difference from EuroQoL.

Vinik et al showed there were reduction of mean change of Utah Early Neuropathy Scale (UENS) from baseline (estimated mean difference versus SOC alone; 90\% CI for difference) of patients which treated with 30 minute use capsaicin $8 \%$ patch and SOC $-2.1(-0.9 ; 95 \%$ CI, -1.8 to 0.1 , treated with 60 minute use capsaicin 8\% patch and SOC -3.0 (-1.7; $95 \%$ CI, -2.7 to -0.8 ), and SOC alone -1.2 .

For sensory perception and reflex testing result, all studies reported no negative results at baseline and the end of the study. Simpson et al showed there was increase report from patient to 'normal' sensation and reduce the report of 'painful' sensation. Vinik et al also showed there was improvement of sensory perception in intervention group with greatest change in 60-min capsaicin $8 \%$ patch group.
All study also reported there were other pain medications during this study (62.8-76.3\%) in both of groups. The most common pain medication used is analgesics agents (50.6-57.5\%), followed with antiepileptic drugs (34.6-47.1\%), antiinflammatory/antirheumatic drugs (18.6$30.6 \%$ ), topical joint/muscular pain products (18.1-30.1\%), and psycholeptics drugs (14.0-25.8\%). One study also reported the use of stomatological preparations (11.5$14.0 \%)$, psychoanaleptics (3.8-13.5\%), and ophtamologicals (9.6-12.7\%).

There were also adverse event reported from all studies which all adverse events were more reported in intervention group (from 46.8-69.4\%) than in control group (33.9-48.4\%). Adverse events are including burning sensation in patch site in skin, pain in extremities, application site pain, and application site erythema. No one participant has drug-related problems that caused dropout or death.
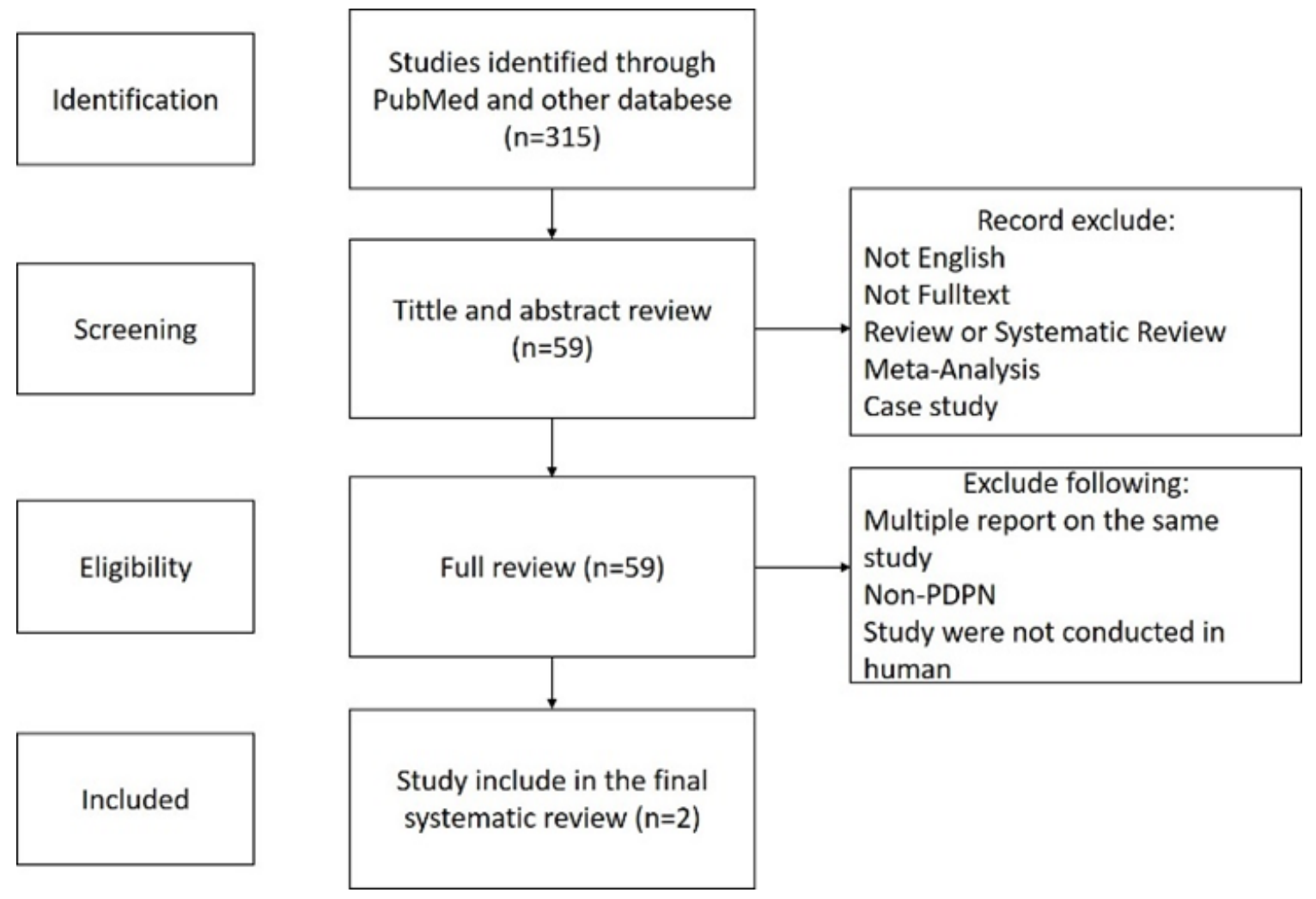

Figure 1. Flowchart of article screening and eligibility 


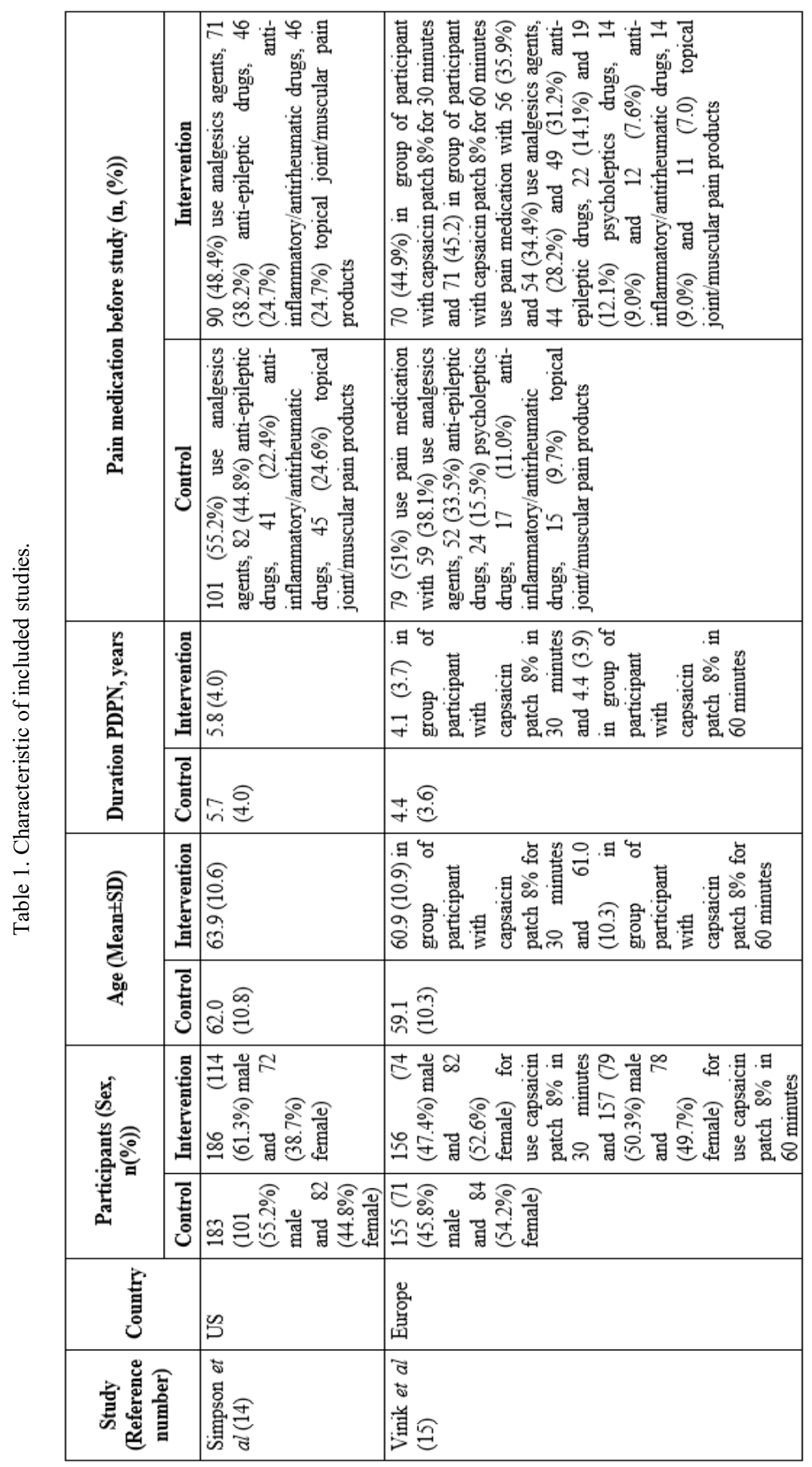




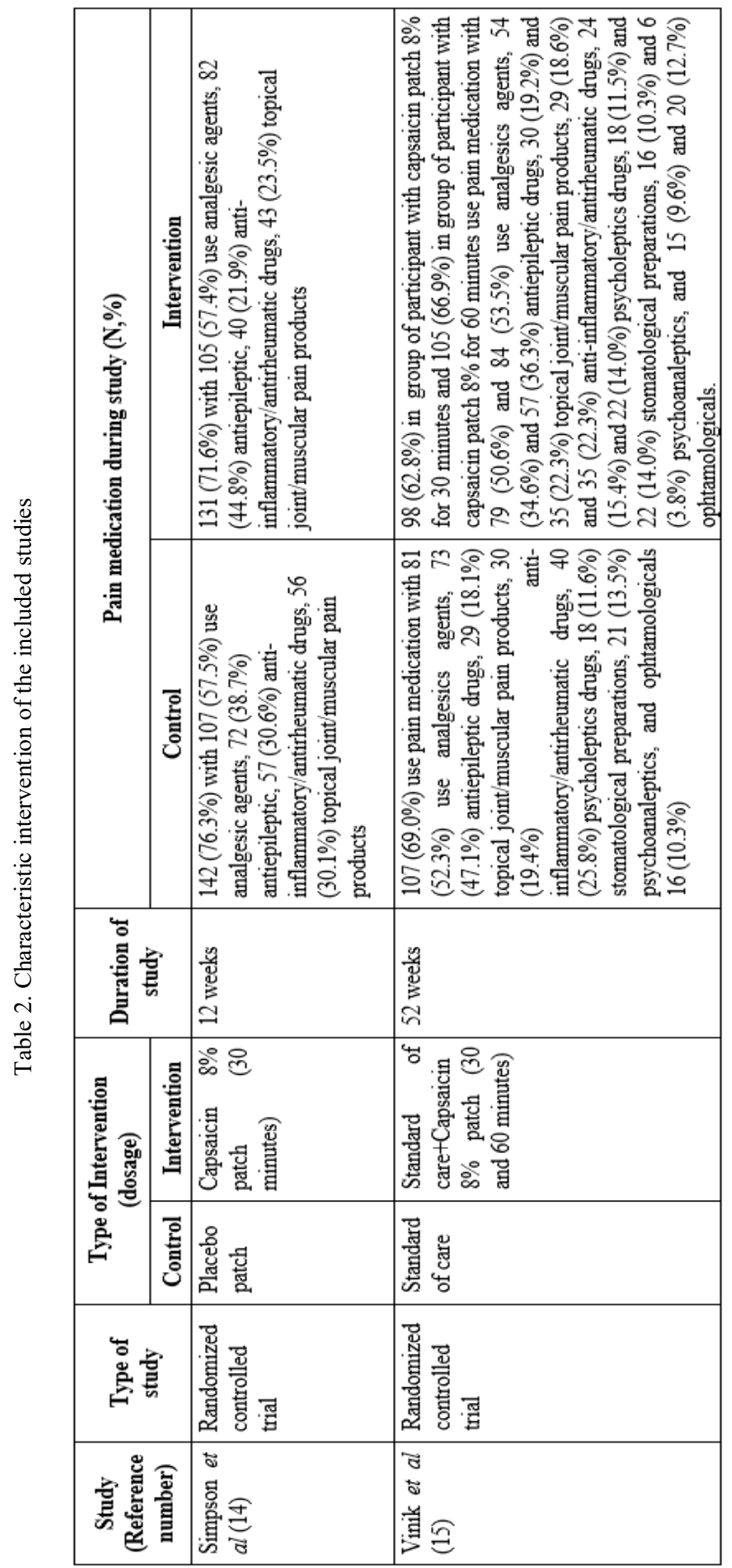




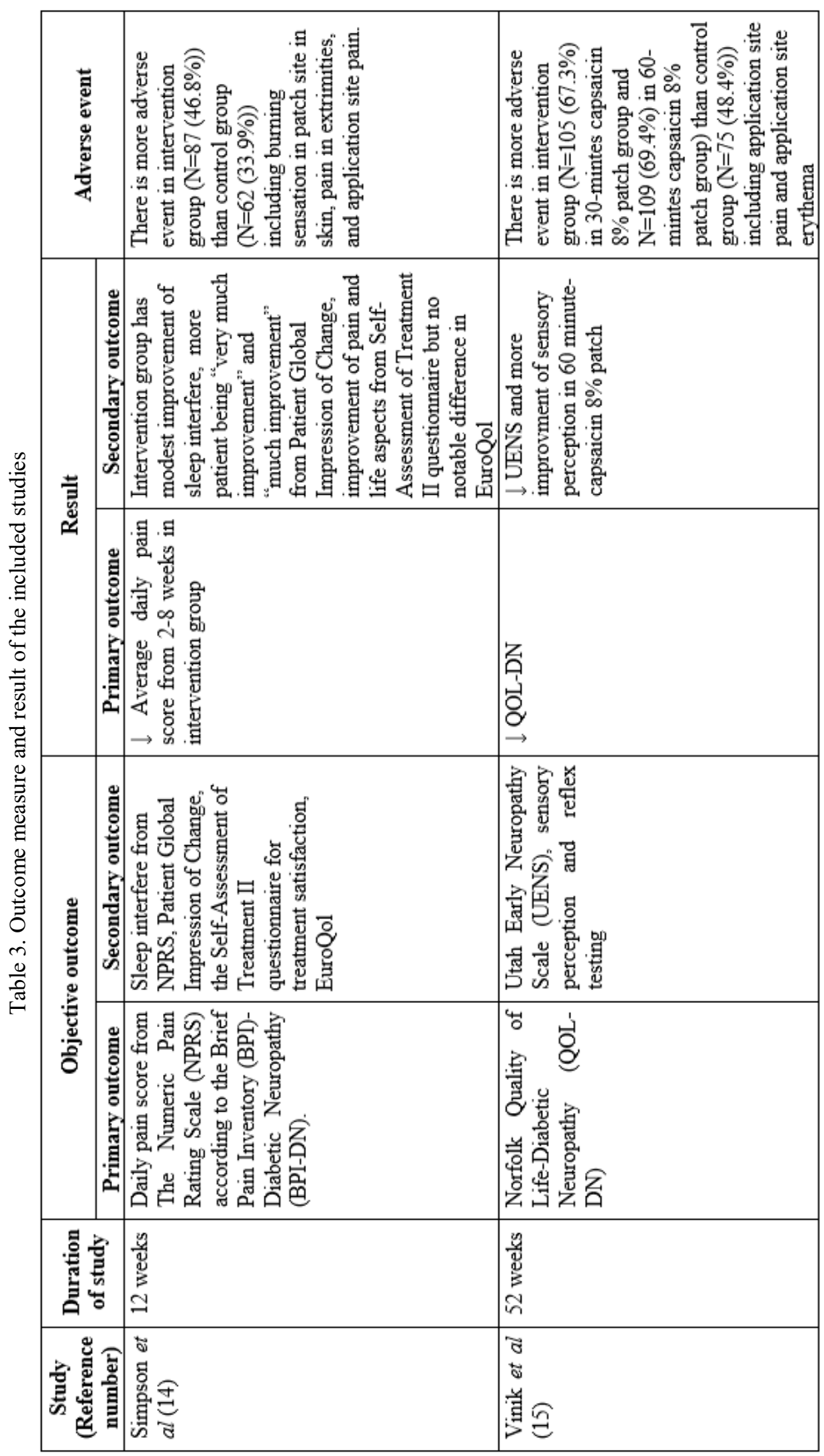




\section{DISCUSSION}

This review focuses on assessing the effectiveness of using the capsaicin $8 \%$ patch for pain relief in PDPN patients. Although there have been several studies comparing the use of capsaicin $8 \%$ patch to relieve pain in PDPN patients with the comparison with other pain medication, studies that focus on the effectiveness of using the capsaicin $8 \%$ patch are still not many. ${ }^{13}$ Although the outcome measurement performed for each study were different, all studies showed the effect of capsaicin $8 \%$ patch to reduce the effect of pain in PDPN patients. ${ }^{14,15}$

Subjective measures of the quantity of pain and impact on patients are key to pain management, although current assessments lack reliability and risk of bias due to the subject's ability to perceive pain differently. ${ }^{16}$ The use of the NPRS as the primary outcome has been widely used to assess the mean pain score during 24 hours of treatment. ${ }^{11,17}$ Although pain assessment is subjective, the use of pain scores is useful for screening non-specialists to identify pain and response to treatment used. ${ }^{18}$ Measurement of the mean daily pain value of PDPN patients with the capsaicin $8 \%$ patch showed that the effect of intervention with the capsaicin $8 \%$ patch had an effect on relieving pain felt by the patient.

Measuring the quantity of pain can also be done to determine the effect of pain on the patient's quality of life. ${ }^{19}$ Pain in PDPN patients is characterized by chronic pain which in the long term can influence the quality of life of diabetic patients. ${ }^{20}$ Therefore, assessment of patient-related outcomes (PROs) is needed to evaluate health services and medical treatment decisions needed for pain management in PDPN patients. ${ }^{21}$ Choosing a good treatment by doctors can help PDPN patients reduce the burden of disease and thus improve the patient's quality of life. ${ }^{22}$ For both studies, the capsaicin $8 \%$ patch was used for both the short term (12 weeks) and the long term (52 weeks). ${ }^{14,15}$

The use of capsaicin substances can also improve nerve function and reduce pain in neuropathic pain. ${ }^{23}$ Chronic pain that occurs in PDPN is mediated by activation of the transient receptor potential vanilloid subtype 1 (TRPV1), a $\mathrm{Ca} 2+$ permeable ion channel, which is expressed on $\mathrm{C}$ and $\mathrm{A} \delta$ nociceptive sensory nerves. ${ }^{24,25}$ TRPV1 is a capsaicin receptor that works to de-functionalize nerve fibers through influx $\mathrm{Ca} 2+$ overload, causing mitochondrial dysfunction as well as reducing nerve fiber function. ${ }^{12}$ In several studies, the effect of capsaicin at high doses showed better analgesic effects than low doses $(8 \%$ vs $0.025 \%$ and $0.075 \%){ }^{26}$ Although the pathophysiology of PDPN is still unclear, this existing study shows that capsaicin can help improve nerve function in PDPN patients. ${ }^{27}$

This review has several limitations. First, a literature search that focused on studies reported in English, limited other studies that were not in English. Although this condition is prone to bias in literature searches, most studies regarding the use of capsaicin $8 \%$ patch in PDPN patients were conducted in English-speaking populations and published reports in English. Therefore, this review does not include studies published in other languages.

In addition, outcome measures used subjective assessments, namely assessments based on the level of pain felt by the patient. As previously discussed, the pain assessment for each person is different, making it difficult to validate the level of pain felt by the patient. The assessment of pain status influenced the pain management prescribed to the patient, in which the patient was also given pain medication throughout the study, thereby influencing the assessment of the level of pain that the patient felt. ${ }^{28}$ The assessment of pain by the patient also influences the patient's perception of the quality of life-related to health, so it becomes a focus regarding the choice of patient therapy. ${ }^{29,30}$

Another limitation is the limited literature search in the last 10 years, where the limitation of the search relates to the use of capsaicin $8 \%$ patch which was approved by the Food and Drug Association (FDA) in 2009 for use as a long-term pain reliever in 
cases of post-herpetic neuralgia $(\mathrm{PHN}){ }^{31}$ Restrictions on the literature search were undertaken aimed at reducing the risk of damage and insecurity from drugs which may increase the risk of adverse side effects. However, restricting the literature search regarding the risk of damage and insecurity of the study carried out can risk positive bias because researchers want to report positive effects of their study that lead to misinformation consequences among researchers, physicians and policymakers. ${ }^{32}$ In this review, the authors minimized the risk of bias by including all adverse events reported in the study.

\section{CONCLUSION}

The use of capsaicin patch $8 \%$ can be a pain reliever and improve the quality of life in PDPN patients. Further studies in a wider population are needed to assess the effectiveness and safety of using the $8 \%$ capsaicin patch as a pain reliever and its effect on improving nerve for PDPN patients.

\section{ACKNOWLEDGMENT}

The abstract part was presented at The 4th APCMS 2021 (Asia-Pacific Cardio Metabolic Syndrome) Congress on 23-24 April 2021 organized by the Korean Society of Metabolic Syndrome.

\section{REFERENCE}

1. Papatheodorou K, Papanas N, Banach M, Papazoglou D, Edmonds M. Complications of Diabetes 2016. J Diabetes Res. Hindawi Publishing Corporation; 2016;2016. PMID: 27822482

2. Abdul M, Khan B, Hashim MJ, King JK, Govender RD, Mustafa H, Kaabi J Al. Epidemiology of Type 2 Diabetes - Global Burden of Disease and Forecasted Trends. J Epidemiol Glob Health. 2020;10:107-111.

3. Lin X, Xu Y, Pan X, Xu J, Ding Y, Sun $X$, Song X, Ren Y, Shan PF. Global, regional, and national burden and trend of diabetes in 195 countries and territories: an analysis from 1990 to 2025. Sci Rep [Internet]. Na- ture Publishing Group UK; 2020;10 (1):1-11.

4. Kosiborod M, Gomes MB, Nicolucci A, Pocock S, Rathmann W, Shestakova M V., Watada H, Shimomura I, Chen H, Cid-Ruzafa J, Fenici P, Hammar N, Surmont F, Tang F, Khunti K. Vascular complications in patients with type 2 diabetes: Prevalence and associated factors in 38 countries (the DISCOVER study program). Cardiovasc Diabetol [Internet]. BioMed Central; 2018;17 (1):1-13.

5. Schreiber AK. Diabetic neuropathic pain: Physiopathology and treatment. World J Diabetes. 2015;6 (3):432.

6. Wicks CW, Selvin E. Epidemiology of Peripheral Neuropathy and Lower Extremity Disease in Diabetes. Curr Diab Rep. 2019;19(10)(86).

7. Feldman EL, Callaghan BC, PopBusui R, Zochodne DW, Wright DE, Bennet DL, Bril V, Russell JW, Viswanathan V. Diabetic neuropathy. Nat Rev Dis Prim [Internet]. 2019 Dec 13;5(1):42.

8. Zoungas S, Arima H, Gerstein HC, Holman RR, Woodward M, Reaven P, Hayward RA, Craven T, Coleman RL, Chalmers J. Effects of intensive glucose control on microvascular outcomes in patients with type 2 diabetes: a meta-analysis of individual participant data from randomised controlled trials. Lancet Diabetes Endocrinol [Internet]. Elsevier Ltd; 2017;5(6):431-437.

9. Ardeleanu V, Toma A, Pafili K, Papanas N, Motofei I, Diaconu CC, Rizzo M, Stoian AP. Current pharmacological treatment of painful diabetic neuropathy: A narrative review. Med. 2020;56(1):1-10. PMID: 31936646

10. Fattori V, Hohmann MSN, Rossaneis AC, Pinho-Ribeiro FA, Verri WA. Capsaicin: Current understanding of its mechanisms and therapy of pain and other pre-clinical and clinical uses. Molecules. 2016;21(7):1- 
33. PMID: 27367653

11. Mankowski C, Poole CD, Ernault E, Thomas R, Berni E, Currie CJ, Treadwell C, Calvo JI, Plastira C, Zafeiropoulou E, Odeyemi I. Effectiveness of the capsaicin $8 \%$ patch in the management of peripheral neuropathic pain in European clinical practice: The ASCEND study. BMC Neurol. BMC Neurology; 2017;17 (1):1-11. PMID: 28431564

12. Anand P, Bley K. Topical capsaicin for pain management: Therapeutic potential and mechanisms of action of the new high-concentration capsaicin 8 patch. Br J Anaesth. 2011;107 (4):490-502.

13. van Nooten F, Treur M, Pantiri K, Stoker M, Charokopou M. Capsaicin 8\% Patch Versus Oral Neuropathic Pain Medications for the Treatment of Painful Diabetic Peripheral Neuropathy: A Systematic Literature Review and Network Meta-analysis. Clin Ther [Internet]. Elsevier HS Journals, Inc.; 2017;39(4):787803.e18.

14. Simpson DM, Robinson-Papp J, Van J, Stoker M, Jacobs H, Snijder RJ, Schregardus DS, Long SK, Lambourg B, Katz N. Capsaicin 8\% Patch in Painful Diabetic Peripheral Neuropathy: A Randomized, Double -Blind, Placebo-Controlled Study. J Pain. 2017;18(1):42-53. PMID: 27746370

15. Vinik AI, Perrot S, Vinik EJ, Pazdera L, Jacobs H, Stoker M, Long SK, Snijder RJ, van der Stoep M, Ortega E, Katz N. Capsaicin 8\% patch repeat treatment plus standard of care (SOC) versus SOC alone in painful diabetic peripheral neuropathy: A randomised, 52-week, openlabel, safety study. BMC Neurol [Internet]. BMC Neurology; 2016;16 (1):1-14.

16. Xu X, Huang Y. Objective Pain Assessment: a Key for the Management of Chronic Pain. F1000Research [Internet]. 2020 Jan 23;9:35.

17. Hansson P, Jensen TS, Kvarstein G,
Strömberg M. Pain-relieving effectiveness, quality of life and tolerability of repeated capsaicin $8 \%$ patch treatment of peripheral neuropathic pain in Scandinavian clinical practice. Eur J Pain [Internet]. 2018 May;22(5):941-950.

18. May S, Serpell M. Diagnosis and assessment of neuropathic pain. F1000 Med Rep. 2009;1(October):2 -5 .

19. Bates D, Schultheis BC, Hanes MC, Jolly SM, Chakravarthy K V., Deer TR, Levy RM, Hunter CW. A Comprehensive Algorithm for Management of Neuropathic Pain. Pain Med [Internet]. 2019 Jun 1;20 (Supplement_1):S2-S12.

20. Bouhassira $\bar{D}$, Letanoux M, Hartemann A. Chronic Pain with Neuropathic Characteristics in Diabetic Patients: A French Cross-Sectional Study. PLoS One. 2013;8(9):1-9. PMID: 24058527

21. Smith SC, Lamping DL, Maclaine GDH. Measuring health-related quality of life in diabetic peripheral neuropathy: A systematic review. Diabetes Res Clin Pract [Internet]. Elsevier Ireland Ltd; 2012;96(3):261 -270 .

22. Hovaguimian A, Gibbons CH. Clinical approach to the treatment of painful diabetic neuropathy. Ther Adv Endocrinol Metab. 2011;2 (1):27-38.

23. Sultana A, Singla RK, He X, Sun Y, Alam MS, Shen B. Topical Capsaicin for the Treatment of Neuropathic Pain. Curr Drug Metab [Internet]. 2021 Apr 21;22(3):198-207.

24. Arora V, Campbell JN, Chung MK. Fight fire with fire: Neurobiology of capsaicin-induced analgesia for chronic pain. Pharmacol Ther [Internet]. 2021;220:107743.

25. Palazzo E, Luongo L, de Novellis V, Berrino L, Rossi F, Maione S. Moving towards supraspinal TRPV1 receptors for chronic pain relief. Mol Pain [Internet]. BioMed Central Ltd; 2010;6(1):66. 
26. Peppin JF, Pappagallo M. Capsaicinoids in the treatment of neuropathic pain: A review. Ther Adv Neurol Disord. 2014;7(1):22-32.

27. Rosenberger DC, Blechschmidt V, Timmerman H, Wolff A, Treede RD. Challenges of neuropathic pain: focus on diabetic neuropathy [Internet]. Journal of Neural Transmission. Springer Vienna; 2020.

28. Flüß E, Bond CM, Jones GT, Macfarlane GJ. The re-evaluation of the measurement of pain in population-based epidemiological studies: The SHAMA study. Br J Pain. 2015;9(3):134-141.

29. Dermanovic Dobrota V, Hrabac P, Skegro D, Smiljanic R, Dobrota S, Prkacin I, Brkljacic N, Peros K, Tomic M, Lukinovic-Skudar V, Basic Kes V. The impact of neuropathic pain and other comorbidities on the quality of life in patients with diabetes. Health Qual Life Out- comes. 2014;12(1):1-8. PMID: 25468384

30. Kamradt M, Krisam J, Kiel M, Qreini M, Besier W, Szecsenyi J, Ose D. Health-related quality of life in primary care: Which aspects matter in multimorbid patients with type 2 diabetes mellitus in a community setting? PLoS One. 2017;12(1):1-14. PMID: 28125691

31. Yong YL, Tan LTH, Ming LC, Chan KG, Lee LH, Goh BH, Khan TM. The effectiveness and safety of topical capsaicin in postherpetic neuralgia: A systematic review and metaanalysis. Front Pharmacol. 2017;7 (JAN):1-12.

32. Mlinarić A, Horvat $M$, Šupak Smolčić V. Dealing with the positive publication bias: Why you should really publish your negative results. Biochem Medica [Internet]. 2017 Oct 15;27(3):1-6. 